Article

\title{
Creative Character Education in Mathematics for Prospective Teachers
}

\author{
Dong-Joong Kim ${ }^{1}$, Sung-Chul Bae ${ }^{1}$, Sang-Ho Choi ${ }^{1}$, Hee-Jeong Kim ${ }^{2}{ }^{-1}$ and Woong Lim ${ }^{3,4, *} \mathbb{C}$ \\ 1 Department of Mathematics Education, Korea University, Seoul 02841, Korea; \\ dongjoongkim@korea.ac.kr (D.-J.K.); niceday707@hanmail.net (S.-C.B.); shchoi83@korea.ac.kr (S.-H.C.) \\ 2 Department of Mathematics Education, Hongik University, Seoul 04066, Korea; heejeongkim@hongik.ac.kr \\ 3 Graduate School of Education, Yonsei University, Seoul 03722, Korea \\ 450 Yonsei-ro, Seodaemun-gu, Seoul 03722, Korea \\ * Correspondence: woonglim@yonsei.ac.kr; Tel.: +82-2-2123-3262
}

Received: 8 January 2019; Accepted: 16 March 2019; Published: 21 March 2019

check for updates

\begin{abstract}
This study examines preservice teachers' perspectives of creativity and character education in mathematics through a university-based teacher education program. We developed a curricular unit on creative character education in a mathematics methods course and investigated participants' $(n=56)$ emerging perspectives of teaching creativity and character by the integration of content and process in mathematics. Data were collected through pre- and post-questionnaires and transcribed course discussion and presentation sessions. A quantitative analysis of the questionnaires through a t-test confirmed key changes in participants' perspectives, while the qualitative context of data illustrates the participants' emergent views on creative character education in mathematics. Overall, findings suggest that a mathematics teacher education curriculum integrating mathematical creativity and character education has the potential to prepare future educators to implement pedagogy that bridges between process and content in school mathematics for the next generation of learners.
\end{abstract}

Keywords: creativity education; character education; creative character education; mathematics teacher education

\section{Introduction}

Today's classrooms are on the brink of a technological and industrial revolution that can fundamentally change the way we think about teaching and learning. Our students need to inquire into the many ever-changing ways in which knowledge is constructed, connected, and created; we believe creativity is deeply rooted in such activities that expand knowledge. Equally important is the opportunity to develop communication skills through collaboration within communities of learners and teachers. With the potential to connect people with diverse cultural assets across geographies and disciplines, a character education curriculum which provides the positive social experiences of building trust and relationships with others in the classroom community is increasingly important $[1,2]$.

Along with the importance of integrating creativity and character as an emerging educational paradigm that bridges content and process, the goals of international (mathematics) education systems have begun to reflect the importance of creativity and character education. For example, the national educational standards in the U.S. [3,4] and the U.K.'s National Advisory Committee on Creative and Cultural Education [5] emphasize developing students' mathematical creativity and their awareness of mathematical values. In our regional context, the Korean Ministry of Education [6] also identified creativity and character building education as an important future educational practice for our students. Research on creativity and character building has explored subdomains of each construct and developed scales to investigate relationships between those two constructs [7]. Research in teacher 
education initially investigated ways of training teachers to foster student creativity [8,9], while recent research has underscored the role of teachers in supporting students as they develop creativity and character [10].

However, the research on educator efforts to design and implement a pedagogy addressing both creativity and character education in the mathematics classroom is scarce. In particular, there exist few studies on the curriculum of creativity and character education in university-based teacher education programs. One way to describe creative character education is the kind of educational space where students develop mathematical thinking and creativity through mathematical activities. Also, inside this educational space, learning processes are regulated and facilitated through productive social and academic interactions [11], which leads to positive student character. With the vision of creative character education in mathematics classrooms, it is warranted to implement a teacher education curriculum focused on creativity and character education, and to study the impact on preservice teachers' changing perspectives towards creativity and character education. This study implemented a curriculum of mathematics creativity and character building in teacher education, with an aim to prepare preservice teachers to implement an integrated pedagogy of creativity and character education in the classroom. Our interest in investigating the impact of a curricular unit on preservice teachers' emerging views on creativity and character education led us to the following research question: To what extent does a curricular unit which integrates creativity and character education, along with mathematical content and process, influence preservice teachers' perspectives towards creativity and character education in the mathematics classroom?

\section{Theoretical Background}

\subsection{Mathematical Creativity}

There are plural definitions of mathematical creativity. Mathematical creativity, compared to creativity in a more general sense, is widely known as the ability involved with concept-developing and problem-solving processes in mathematics. Early theories on mathematical creativity include Poincare's research on creativity as insight through intuition in relationships between mathematical problem solving and the unconscious. Wallas [12] posed another early theory of mathematical creativity, claiming that creativity is nurtured from the unconscious work of incubation and then externalized through symbols, words, and logic. These early studies of creativity contributed to the theoretical foundation of mathematical problem-solving models thereafter, such as Polya's and Schoenfeld's notion of heuristics.

As problem solving has become a regular part of mathematics instruction, so has the educator's interest in framing creativity within the strategies of problem solving. Divergent thinking is often used as a strategy to generate multiple creative ideas, and is regarded as an important component for mathematical creativity by contrasting convergent thinking. Convergent thinking is a technique that structures and organizes various ideas from different participants and attempts to culminate in one best solution to a question. However, both are crucial for developing mathematical creativity as these strategies point to the importance of connecting existing ideas in order to build new ideas. When mathematical creativity is defined as the process of making unique and insightful results for a problem, this connection of building ideas is an important process in mathematically creative thinking [13].

On the other hand, research proposed different types of mathematical creativity for different contexts. For instance, Liljedahl and Sriraman [14] suggested distinguishing school-level creativity from professional-level creativity. Professional-level creativity refers to originality or ingenuity in academic products for discovering what was previously unknown. School-level creativity is the process of developing exceptional and unconventional solutions in problem solving. School-level mathematical creativity also encompasses gaining the knowledge of school mathematics, integrating disconnected ideas, and building new relationships. As described next, considering creativity in this study, we noted 
the importance of mathematical tasks that afford students opportunities to communicate and use tools in describing an appropriate level of creativity for students.

\subsection{Creativity Education Program in the Study}

In designing a unit to support participants as they learn to conceptualize a pedagogy for facilitating student creativity in the mathematics classroom, we propose a student-centered method consisting of three specific approaches: storytelling, use of manipulatives, and use of multiple representations. More specifically, our curriculum provides preservice teachers with educational contexts in which students participate in story-based, problem-solving tasks using technology or manipulatives. The use of technology and manipulatives allows students to explore various representations of mathematical thinking and reasoning, and to produce diverse solutions to problems; our participants were asked to engage in these problems as learners.

This approach builds upon a research base on the educational opportunity to (1) build a rich conception of situations and to express concepts and ideas through storytelling [15]; (2) build relationships between concepts and objects through the use of manipulatives; and lastly (3) link relationships in a network of ideas and to engage in problem solving through the use of various representations, including those demonstrated through technology. In this way, the use of storytelling, manipulatives, and multiple representations combine to afford meaningful opportunities for students to engage in inductive reasoning, synthesis, and ultimately creativity in the mathematics classroom [16]. Table 1 shows the literature to categorize subdomains of creativity and to support our rationale for the connection between creativity and teacher practice in the classroom [7].

Table 1. Creativity subscales fostered by tool-mediated teaching practices [7].

\begin{tabular}{ccc}
\hline Creativity & Reference & Practice \\
\hline Inquisitive mindset & $\begin{array}{c}\text { Ahn, 2014 [17] } \\
\text { Son \& Jeong, 2013 [18] }\end{array}$ & Storytelling \\
\hline Usefulness & Kim et al., 2013 [19] & \\
\hline Imagination & Egan, 2001 [20] & Use of manipulatives \\
\hline Divergent thinking & Kwon, Park, \& Park, 2006 [21] & \\
\hline Fluency & Lee \& Shim, 2007 [22] & \\
\hline Flexibility & Lee \& Shim, 2007 [22] & \\
\hline Critical thinking & Lee \& Choi, 2013 [23] & \\
\hline Visualization & Kolden et al., 2010 [24] & \\
\hline Kwon et al., 2006 [2] & Dienes, 1960 [25] & \\
\hline Opentrarian thinking & Lee \& Lee, 2012 [26] & Use of technology \\
\cline { 1 - 2 } Convergent thinking & Lee \& Lee, 2012 [26] & \\
\hline
\end{tabular}

Storytelling. Teachers can use stories as a learning tool in the mathematics classroom [15]. More specifically, stories can foster creativity in students by prompting their interest, curiosity, sensitivity, and imagination about mathematics. These stories can be told through mathematical enrichment activities, using the history of mathematics and mathematicians, diverse mathematical ideas, structures, modeling situations, and other cultural artifacts [28]. As the teacher tells stories, students can use the information, as well as their imagination, to understand the narrative accounts and construct their own. In this sense, stories can engage students in the process of learning [29].

Use of manipulatives. Use of manipulatives in the mathematics classroom is a student-centered process in which students touch and move objects while they explore and connect mathematical ideas 
to ultimately expand their creativity. Manipulatives are cognitive tools that are a dynamic visual representation of otherwise abstract mathematical ideas. The theory of experiential learning states that learning is meaningful when students acquire knowledge through active processes that engage mind and body [30]. Further, an appropriate use of manipulatives enables students to objectify abstract concepts, helping students transition from concrete experiences to abstract reasoning [31-33].

Use of multiple representations. Mathematical representation refers to the ways of capturing an abstract mathematical concept or relationship [34]. A mathematical representation may be either symbolic in nature or more of an internal way of thinking about mathematical meanings [35]. Regardless of their form, Duval [36] asserts that representations are essential to communicate meaning drawn from or evident with mathematical objects and concepts. For example, using multiple representations can support students in visualizing (e.g., diagrams and graphs) mathematical concepts, making connections, and creating new ideas. Through activities with multiple representations, including various modes of expression (e.g., speaking, writing) for communication, students broaden their repertoire of illustrating mathematical ideas and gain deeper mathematical understanding.

\subsection{Character in Mathematics Education}

Character is defined in the field of education as moral qualities, ethical values, and responsibility for self and others in society. Character education involves students developing a moral sense and positive character traits [37]. Traditionally, character education in schools belonged to civics classes which taught respect, responsibility, and caring for family and community members. However, there has been increasing interest in teaching moral and civic virtues through academic content [38,39]. Interest has also risen as to how the kinds of civic education that promote a responsible citizenry can be used in conjunction with curriculum on creativity. Particularly, the national curriculum in Korea [40] emphasizes the key abilities of creative thinking and a sense of community; competence of each is related to character education. Similarly, in the U.S., Common Core State Standards for Mathematics [3] highlights the mathematical practices involving perseverance in solving mathematical problems in addition to the mathematical content. In this study, we use the term character not to distinguish it from other terms, such as disposition or personality, but more to attend to the kinds of social-emotional development promoted and nurtured through learning in educational contexts.

Educational philosophers such as Pestalozzi, Herbart, and Froebel have highlighted character education as an important component of mathematics education [41]. According to Pestalozzi, the goal of mathematics education as an essential discipline to cultivate character is developing cognition and powers of thought. Similarly, Woo [42] stated learning mathematics paralleled performing mental gymnastics such as judgment and inference, thus teaching mathematics to include character education can lead students to exercise judgment and justice in the moral sense. These views point to the potential of mathematics instruction to inculcate not only the nature of mathematical truth, but also aesthetic and moral values.

\subsection{Character Education Program in the Study}

Beginning with group processing [43], we attended to the importance of learning through positive interactions with others in the classroom. This theory posits a close relationship between positive interdependence and cultivation of character through how relationships with peers influence individual behavior for psychological process and goal achievement.

Our approach builds upon a research base to identify three process-based teaching practices with the potential to foster student character. Table 2 shows the literature that supports the connection between the elements of character and teacher practices to promote process-based learning in the classroom. 
Table 2. Character subscales fostered by process-based teaching practices [7].

\begin{tabular}{ccc}
\hline Character & Reference & Practice \\
\hline Consideration & Lopez \& Allal, 2007 [44] & \\
\hline Confidence & Seo \& Ahn, 2003 [45] & \\
\hline Participation & Johnson \& Johnson, 2005 [43] & Classroom norms \\
Nesponsibility & Lopez \& Allal, 2007 [44] & \\
\hline Cense of community & Johnson \& Johnson, 2005 [43] & Collaborative learning \\
\hline \multirow{2}{*}{ Responsibility, honesty, justice } & Seo \& Ahn, 2003 [45] & Multirater feedback \\
\hline
\end{tabular}

Classroom norms. Classroom norms are an important construct for the analysis of classroom cultures [48]. In this study, we considered socio-mathematical norms of the classroom community, including the normative aspects of student behaviors and interactions in the learning of mathematics [49]. The development of classroom norms would involve students debating acceptable social norms and ways to participate in mathematical discourse in order to create a safe and productive mathematics-learning environment. Then, the students selected the norms for their classroom and learned to cultivate acceptable social and mathematical behaviors, which are evident in character traits such as: respect, kindness, responsibility, helping, persistence, reasonableness, and/or productivity. As classroom norms are associated with future behavior in the classroom [50], when students exercise the classroom norm, for example, supporting each other in listening actively, contributing ideas, and sharing struggles, students have the opportunity to build characteristics such as kindness, respect, and productivity.

Collaborative learning. Collaborative learning is an educational approach in which groups of learners work together to accomplish shared learning goals [51]. Research has claimed that as students participate in collaborative learning and practice social skills, they have the opportunity to develop core virtues such as leadership, responsibility, and cooperation [52]. In this study, the meaning of learning mathematics is believed to lie in the participatory opportunity to communicate mathematical knowledge with others in the community. Therefore, collaborative learning can provide space and opportunity in which to develop concepts within the learner and to use the communication with others as negotiation of knowledge and experience to change thinking with new or improved ideas. As the learner works collaboratively with the teacher and peers, and as they participate in the negotiation of knowledge and ideas, the ability to listen to others and engage in this meaningful conversation may positively address a number of emerging challenges such as bullying or harassment.

Multirater feedback. The multirater feedback approach is a type of assessment in which individuals working as part of a group are asked to offer feedback on the peer's performance [53]. Multiple performance feedback provides a student with the opportunity to analyze, assess, and improve his or her learning in light of support and collegial feedback from members of the classroom community. It makes the student aware that being successful is not solely about pleasing the teacher-success is identified in the process of working with peers, helping others who share goals or problems find success, and improving oneself. In the context of this study, multiple methods of assessment for character education such as group-, peer-, and self-evaluation are designed and implemented in the classroom. Evaluations by teacher, self, and peers are intended to enrich components of character such as responsibility and fairness in oneself, as well as in the classroom norms which reflect the values and beliefs of the classroom community. Additionally, designing assessments in which students engage in evaluating knowledge across various modes of communication can help 
individual students recognize the intellectual contributions of others in the community as equal in value to the dominant knowledge.

Integrated approach: Creativity and character education. In the study, we define creative character education as an integrated educational approach which fosters both mathematical creativity and character in the mathematics classroom. Our design of the creative character education program is summarized in Figure 1.

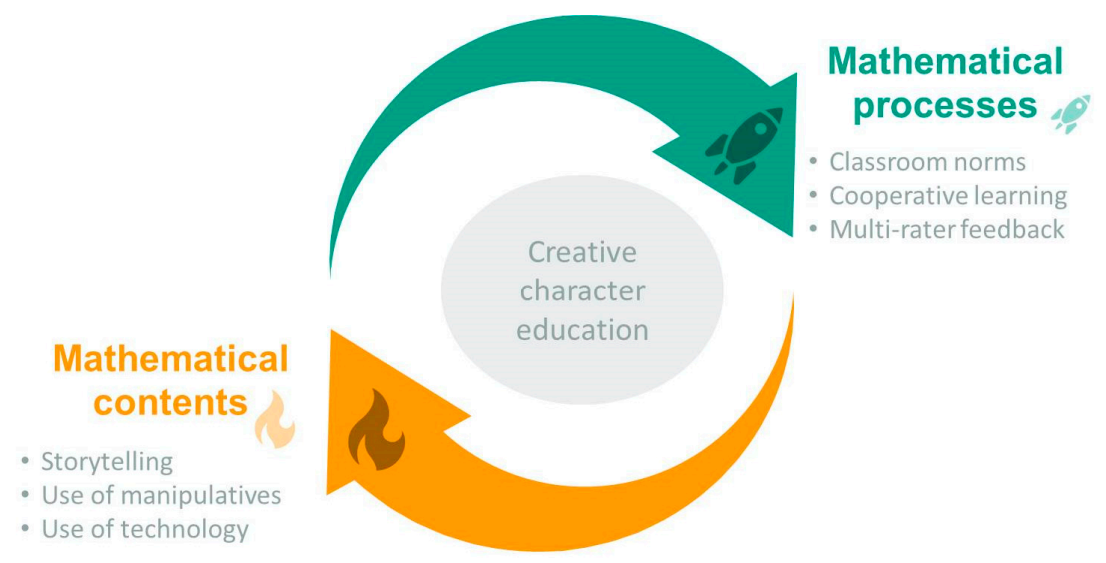

Figure 1. Design of the creative character education program.

Research on creativity in mathematics education has been conducted separately from the research on character education. An education geared towards creativity may overlook the importance of cooperation and group work, while on the other hand, character education may overlook mathematical content. While multiple studies on mathematical creativity education have provided investigation into concept, learning, teaching, and problem solving $[13,54]$, there have been few studies on character building in mathematics education. In light of the need for research on the integration of creativity and character education, to include the initial pedagogical models in teacher education, this study investigated a new model of pedagogy in the context of teacher education. Extending the literature on creativity and character in education, we frame creativity in the mastery of content through pedagogical strategies such as storytelling and the use of manipulatives and representations. Character education is framed in the process (not product) of participatory learning through classroom norms, collaborative learning, and multirater feedback.

\section{Method}

\subsection{Participants}

From a university-based teacher education program in Seoul, Korea, 56 preservice teachers (grades 7-12) volunteered to participate in the study in the spring of 2014. All participants signed informed consent approved by the Institutional Review Board. The participants (33 male and 23 female, age 22-25) had junior or senior standings in the college of education at a private university in Seoul, Korea, and had taken at least 18 credit hours of advanced mathematics and 6 credit hours of mathematics education courses.

\subsection{Data Collection and Analysis}

This study implemented a mixed research method [55]. A quantitative method of research design, along with the description of our curriculum and some supplementary qualitative data as contextual information, was used to investigate the impact of our approach on participating teacher candidates' emerging views of creativity and character education. The main data sources of this study consisted of survey responses and artifacts from participants' activities, including written reflections and transcribed data of student debates and presentations. As part of the study, a questionnaire 
instrument was designed by adapting the survey items of Whang et al. [7], which proposed a survey of 60 items with middle school students as respondents. First, we reviewed the literature and identified the subdomains of creativity and character which were most appropriate for a curriculum for preservice teachers, including storytelling, use of manipulatives and technology, use of representations, classroom norms, collaborative learning, and multirater feedback (i.e., [21,56]). From this, we developed two valid scales (i.e., content and process) that aligned with these subdomains. The questionnaire included a total of 40 items (after omitting redundant or unrelated items from Whang and his colleagues' instrument) with 19 items on the subconstructs of creativity and 21 items on the subconstructs of character education. The alignment of the items and components are provided in Tables 3 and 4 . The pretest was conducted in the first class meeting and the post-test was conducted in the last class meeting of the semester.

Table 3. Alignment of the creativity subscales utilized in the survey instrument (19 items).

\begin{tabular}{clc}
\hline Mathematical Contents & \multicolumn{1}{c}{ Creativity } & Items \\
\hline \multirow{3}{*}{ Storytelling } & 1. Inquisitive mindset & $1,6,7$ \\
& 2. Usefulness & 3,4 \\
& 3. Imagination & 8 \\
\hline \multirow{3}{*}{ Use of manipulatives } & 4. Originality & 12,13 \\
& 5. Fluency & 2,15 \\
& 6. Flexibility & 16 \\
& 7. Critical thinking & $5,10,11,14$ \\
\hline \multirow{2}{*}{ Use of technology } & 8. Visualization & 9,19 \\
& 9. Contrarian thinking & 18 \\
& 10. Precision & 17 \\
\hline
\end{tabular}

Table 4. Alignment of the character subscales utilized in the survey instrument (21 items).

\begin{tabular}{clc}
\hline Mathematical Processes & \multicolumn{1}{c}{ Character } & \multicolumn{1}{c}{ Items } \\
\hline \multirow{3}{*}{ Classroom norms } & 1. Consideration & $27,28,31$ \\
& 2. Confidence & $20,22,33$ \\
& 3. Participation & $23,24,36$ \\
& 4. Grit & 34 \\
\hline Collaborative learning & 5. Sense of community & $21,25,37,38,39,40$ \\
\hline \multirow{3}{*}{ Multirater feedback } & 6. Responsibility & 26,29 \\
& 7. Honesty & 32,35 \\
& 8. Justice & 30 \\
\hline
\end{tabular}

The scale for the items in the questionnaire were encoded from $-2=$ strongly disagree to $2=$ strongly agree. Pre- and post-analysis were performed via the $t$-test for paired samples at a 0.05 alpha level. (Alpha indicates how extreme the data must be before the null hypothesis is rejected. The smaller the alpha, the less likely it is to find a statistically significant result.) The test aimed to determine whether there exists statistical evidence that the mean difference between pre- and post-outcomes is significantly different from zero. Post hoc analyses are performed after a study has been implemented, which can explain possible nonsignificant results. Our post hoc power analysis reported a power of greater than 0.99 at the $5 \%$ alpha level with effect size of 0.8 and a sample of 56 and confirmed the actual effect of our curriculum in the study [57]. The reliability of the 40 items in the questionnaire was evaluated using Cronbach's alpha as the estimate of internal consistency. The value of Cronbach's alpha for the survey of creativity character education was 0.883 , which is considered as a reasonably strong alpha coefficient. Content reliability was ensured through independent review by two mathematics educators; the reviewers then recommended revisions until a consensus for approval was reached. 
Transcribed video data from the participants' pro and con debates, based on their reflection papers, were used as supplemental data to provide contextual information on the quantitative results. Data were also gathered from the participants using final group project presentations on creativity and character education at the end of the semester.

\subsection{The Curriculum}

The participants in this study took part in a unit embedded in a methods course ( 3 credit hours) for 16 weeks; the class met twice a week. The content of the curricular unit included pedagogy with regard to storytelling, manipulatives, and representations in order to foster creativity in the learning of mathematics for twelve weeks. Also featured was teacher practice regarding classroom norms, collaborative learning, and multirater feedback in order to develop character building in the mathematics classroom. All in-class activities were designed to reflect the principles of collaborative learning, including the multirater feedback for performance on assignments and in-class participation, with the goal of improving student collaboration. The participants were asked to create a lesson plan as their final project. The lesson plan was designed to foster students' creativity and promote character building. In this way, the preservice teachers had the opportunity to consider specific ways to implement creative character education in the mathematics classroom. Table 5 describes our curriculum in more detail.

Table 5. Descriptions of the unit in the methods course.

\begin{tabular}{|c|c|}
\hline Week & Description \\
\hline 1 & $\begin{array}{l}\text { - Classroom norms } \\
\text { - } \quad \text { Review the literature on socio-mathematical norms } \\
\text { - Watch video clips of classrooms implementing student-centered mathematics } \\
\text { - } \quad \text { Debsroom norms } \\
\text { - Create socio-mathematical classroom norms }\end{array}$ \\
\hline $2-7$ & $\begin{array}{l}\text { - Storytelling } \\
\text { - Review teaching materials that use storytelling to introduce number expansion, variables } \\
\text { and equations, and Pythagorean theorem } \\
\text { Review exemplary storytelling curricular materials: calculus through the history of } \\
\text { mathematics, mathematical modeling, and the story about a cultural artifact from a } \\
\text { mathematical perspective (Neel, 2005) } \\
\text { - } \quad \text { Engage in writing activity to create storytelling } \\
\text { - Debate the benefits and critiques for implementing storytelling in the math classroom }\end{array}$ \\
\hline $8-10$ & $\begin{array}{l}\text { - Use of manipulatives-doing mathematics with manipulatives } \\
\text { - } \quad \text { Explore three-dimensional figures with the tool Zonodome } \\
\text { - } \quad \text { Game-based activities to play with the tower of Hanoi and Pentominoes } \\
\text { - } \quad \text { Debate about learning math with manipulatives }\end{array}$ \\
\hline $11-13$ & $\begin{array}{l}\text { - Use of representations-engaging in math tasks to experience multiple } \\
\text { mathematical representations } \\
\text { - } \quad \text { Explore graphs of functions with the Calculator-Based Ranger } \\
\text { - } \quad \text { Pngage in representation activities using the Geometer's Sketchpad } \\
\text { - } \quad \text { Debate about implementing representation activities in the classroom }\end{array}$ \\
\hline $14-16$ & - Group presentations on creative character education; class reflections \\
\hline
\end{tabular}




\section{Findings}

\subsection{The Effect of the Unit on Mathematical Creativity}

Relationship between storytelling and mathematical creativity. The $t$-test results revealed that the mean scores for the survey items about participant conceptions of creativity relative to storytelling in the postquestionnaire were significantly higher than those in the prequestionnaire. The $t$-test results presented in Table 6 suggest that the perceived benefits of storytelling on mathematical creativity include the usefulness of mathematics (item 3), inquisitive mindset (items 6 and 7), and imagination (item 8).

Table 6. Benefits of storytelling relative to mathematical creativity $(\mathrm{CI}=$ confidence interval, $\mathrm{M}=$ mean, $\mathrm{SD}=$ standard deviation, $\mathrm{LL}=$ lower limit, $\mathrm{UL}=$ upper limit, $\mathrm{df}=$ degrees of freedom).

\begin{tabular}{|c|c|c|c|c|c|c|c|}
\hline \multirow{2}{*}{ Statement } & \multirow{2}{*}{$\begin{array}{c}\text { Pre } \\
\text { M(SD) }\end{array}$} & \multirow{2}{*}{$\begin{array}{c}\text { Post } \\
\text { M(SD) }\end{array}$} & \multicolumn{2}{|c|}{$95 \% \mathrm{CI}$} & \multirow{2}{*}{$d f$} & \multirow{2}{*}{$t$} & \multirow{2}{*}{$p$} \\
\hline & & & $\mathbf{L L}$ & UL & & & \\
\hline 1. I enjoy mathematics. & $\begin{array}{c}0.75 \\
(0.84)\end{array}$ & $\begin{array}{c}0.75 \\
(0.84)\end{array}$ & -0.19 & 0.19 & 55 & 0 & 1.000 \\
\hline 3. I think mathematics can help us in our daily life. & $\begin{array}{c}0.21 \\
(0.98)\end{array}$ & $\begin{array}{c}0.91 \\
(0.78)\end{array}$ & -0.54 & -0.06 & 55 & -2.55 & $0.014^{*}$ \\
\hline 4. I think mathematics helps to improve thinking skills. & $\begin{array}{c}1.63 \\
(0.49)\end{array}$ & $\begin{array}{c}1.73 \\
(0.45)\end{array}$ & -0.26 & 0.04 & 55 & -1.43 & 0.159 \\
\hline $\begin{array}{l}\text { 6. I am inquisitive about mathematical situations } \\
\text { around me. }\end{array}$ & $\begin{array}{l}-0.16 \\
(0.87)\end{array}$ & $\begin{array}{c}0.36 \\
(0.82)\end{array}$ & -0.75 & -0.28 & 55 & -4.44 & $0.000 * *$ \\
\hline 7. I like to read more about mathematics. & $\begin{array}{c}0.36 \\
(0.84)\end{array}$ & $\begin{array}{c}0.70 \\
(0.81)\end{array}$ & -0.58 & -0.10 & 55 & -2.89 & $0.006^{* *}$ \\
\hline $\begin{array}{l}\text { 8. I use mathematical imagination for making or } \\
\text { proving mathematical conjectures. }\end{array}$ & $\begin{array}{l}-0.21 \\
(0.87)\end{array}$ & $\begin{array}{c}0.05 \\
(0.92)\end{array}$ & -0.46 & -0.08 & 55 & -2.86 & $0.006^{* *}$ \\
\hline
\end{tabular}

To contextualize the significant relationship between storytelling and mathematical creativity evident in the quantitative data, we present our findings from the qualitative data. First, the participants found storytelling useful to provide context and help them better relate to the use of mathematics. Below is a partial response that is representative of participants who support the use of storytelling to illustrate practical applications of mathematics in common life experiences:

Students always ask me why we learn mathematics and how it is related to their lives. I think storytelling is basically telling stories [... ] and these stories are based on people's lived experiences. So, I think storytelling in math can help students see the story of our lives and how math connects with people and their lives. (Excerpt 1-debate)

Second, the participants indicated that storytelling fosters an inquisitive mindset towards mathematical situations. As evident in Excerpt 2, the participants stated that students could develop interest and become motivated to explore mathematics thanks to storytelling about mathematicians, and the history and development of mathematical concepts.

Many textbooks these days include storytelling about how mathematical ideas were developed. Since the stories focus on why those math ideas were needed and how they are related to our real life, I think the stories make our students think more deeply about mathematics and change their views on mathematics. So some students probably have accepted mathematical formulas as given and learn mathematics very passively-but thanks to storytelling, the students now become more active learners because they believe they could develop mathematical ideas on their own, just like the mathematicians did in history. In this way, I believe storytelling promotes a sense of inquiry for students and helps them change their attitudes towards mathematics. I think this is one of the positive aspects of using storytelling in the mathematics classroom. (Excerpt 2-debate) 
Mathematical creativity and manipulatives. In the case of manipulative activities, the participants perceived benefits (Table 7) from using manipulatives in the areas of mathematical creativity, critical thinking (items 10 and 11), and originality (items 12 and 13).

Table 7. Benefits of using manipulatives relative to mathematical creativity.

\begin{tabular}{|c|c|c|c|c|c|c|c|}
\hline \multirow{2}{*}{ Statement } & \multirow{2}{*}{$\begin{array}{c}\text { Pre } \\
\text { M(SD) }\end{array}$} & \multirow{2}{*}{$\begin{array}{c}\text { Post } \\
\text { M(SD) }\end{array}$} & \multicolumn{2}{|c|}{$95 \% \mathrm{CI}$} & \multirow{2}{*}{$d f$} & \multirow{2}{*}{$t$} & \multirow{2}{*}{$p$} \\
\hline & & & LL & UL & & & \\
\hline 2. I am confident in mathematics. & $\begin{array}{c}0.21 \\
(1.02)\end{array}$ & $\begin{array}{c}0.32 \\
(1.01)\end{array}$ & -0.35 & 0.13 & 55 & -0.90 & 0.370 \\
\hline $\begin{array}{l}\text { 5. I enjoy working independently and like to solve } \\
\text { mathematical problems on my own. }\end{array}$ & $\begin{array}{c}0.70 \\
(0.91)\end{array}$ & $\begin{array}{c}0.84 \\
(0.85)\end{array}$ & -0.36 & 0.08 & 55 & -1.31 & 0.197 \\
\hline $\begin{array}{l}\text { 10. I ask "why?" and "what if?" when I engage in } \\
\text { complicated and difficult mathematics. }\end{array}$ & $\begin{array}{c}0.39 \\
(0.87)\end{array}$ & $\begin{array}{c}0.84 \\
(0.99)\end{array}$ & -0.69 & -0.20 & 55 & -3.66 & $0.001^{* *}$ \\
\hline $\begin{array}{l}\text { 11. I am good at attempting multiple strategies in problem } \\
\text { solving. }\end{array}$ & $\begin{array}{c}0.07 \\
(0.78)\end{array}$ & $\begin{array}{c}1.05 \\
(0.67)\end{array}$ & -1.28 & -0.69 & 55 & -6.66 & $0.000 * *$ \\
\hline $\begin{array}{l}\text { 12. Instead of following other people's ways of thinking, I like } \\
\text { to think and explore on my own. }\end{array}$ & $\begin{array}{c}0.41 \\
(0.89)\end{array}$ & $\begin{array}{l}1.38 \\
(0.84)\end{array}$ & -1.28 & -0.65 & 55 & -6.06 & $0.000^{* *}$ \\
\hline $\begin{array}{l}\text { 13. When solving mathematics problems, I try to find a } \\
\text { unique method that is different from traditional methods. }\end{array}$ & $\begin{array}{c}0.27 \\
(0.90)\end{array}$ & $\begin{array}{c}0.48 \\
(0.87)\end{array}$ & -0.42 & -0.01 & 55 & -2.06 & 0.044 * \\
\hline
\end{tabular}

Note. ${ }^{* *} p<0.01,{ }^{*} p<0.05$.

\subsection{Mathematical Creativity and Representation}

In the case of mathematical creativity and representation activities, the participants showed confidence in some components of mathematical creativity (Table 8) such as contrarian thinking (item 18) and visualization (item 19).

Table 8. Benefits of using technology relative to mathematical creativity.

\begin{tabular}{|c|c|c|c|c|c|c|c|}
\hline \multirow{2}{*}{ Statement } & \multirow{2}{*}{$\begin{array}{c}\text { Pre } \\
\text { M(SD) }\end{array}$} & \multirow{2}{*}{$\begin{array}{c}\text { Post } \\
\text { M(SD) }\end{array}$} & \multicolumn{2}{|c|}{$95 \% \mathrm{CI}$} & \multirow{2}{*}{$d f$} & \multirow{2}{*}{$t$} & \multirow{2}{*}{$p$} \\
\hline & & & LL & UL & & & \\
\hline $\begin{array}{l}\text { 9. I can imagine and draw geometric shapes and solid } \\
\text { figures in my head. }\end{array}$ & $\begin{array}{c}0.64 \\
(0.90)\end{array}$ & $\begin{array}{c}0.79 \\
(0.80)\end{array}$ & -0.34 & 0.05 & 55 & -1.48 & 0.146 \\
\hline $\begin{array}{l}\text { 17. I can work with mathematical expressions or } \\
\text { symbols to represent mathematical situations. }\end{array}$ & $\begin{array}{c}0.77 \\
(0.79)\end{array}$ & $\begin{array}{c}0.86 \\
(0.65)\end{array}$ & -0.25 & 0.07 & 55 & -1.15 & 0.255 \\
\hline $\begin{array}{l}\text { 18. I am eager to think in new ways and challenge } \\
\text { traditional ways of thinking. }\end{array}$ & $\begin{array}{c}0.36 \\
(0.94)\end{array}$ & $\begin{array}{c}0.63 \\
(0.91)\end{array}$ & -0.51 & -0.03 & 55 & -2.27 & 0.027 * \\
\hline $\begin{array}{l}\text { 19. Integrating technology as tools for visualization } \\
\text { supports diverse approaches to mathematics. }\end{array}$ & $\begin{array}{c}0.95 \\
(0.92)\end{array}$ & $\begin{array}{c}1.41 \\
(0.68)\end{array}$ & -0.73 & -0.20 & 55 & -3.51 & $0.001^{* *}$ \\
\hline
\end{tabular}

Note. ${ }^{* *} p<0.01,{ }^{*} p<0.05$

\subsection{The Effect of the Unit on Character Education}

Character and classroom norms. In the case of classroom norms, the participants expressed a positive view of implementing classroom norms, seeing benefits (Table 9) such as mathematical confidence (items 20, 22, and 33), participation (items 23, 24, and 36), consideration (items 28 and 31), or grit (item 34 ).

Through the experience of developing classroom norms, some participants realized the importance of setting acceptable communication as the norm in building a positive classroom culture. In addition, the participants perceived that socio-mathematical norms could increase student participation in discussion.

Character and collaborative learning. In the case of character and collaboration (Table 10), the participants indicated that collaborative learning experiences had an impact on their sense of community (items 21,25 , and 37 ). 
Table 9. Benefits of classroom norms relative to character education.

\begin{tabular}{|c|c|c|c|c|c|c|c|}
\hline \multirow{2}{*}{ Statement } & \multirow{2}{*}{$\begin{array}{c}\text { Pre } \\
\text { M(SD) }\end{array}$} & \multirow{2}{*}{$\begin{array}{c}\text { Post } \\
\text { M(SD) }\end{array}$} & \multicolumn{2}{|c|}{$95 \% \mathrm{CI}$} & \multirow{2}{*}{$d f$} & \multirow{2}{*}{$t$} & \multirow{2}{*}{$p$} \\
\hline & & & LL & UL & & & \\
\hline $\begin{array}{l}\text { 20. I am very confident about telling others my opinions } \\
\text { regarding mathematical problems and content. }\end{array}$ & $\begin{array}{c}0.38 \\
(0.96)\end{array}$ & $\begin{array}{c}0.75 \\
(0.90)\end{array}$ & -0.61 & -0.14 & 55 & -3.25 & $0.002 * *$ \\
\hline $\begin{array}{l}\text { 22. If I am convinced of my mathematical thinking, I would } \\
\text { share it in the classroom even though some may disagree. }\end{array}$ & $\begin{array}{c}0.27 \\
(0.96)\end{array}$ & $\begin{array}{c}0.66 \\
(0.90)\end{array}$ & -0.65 & -0.13 & 55 & -3.04 & $0.004^{* *}$ \\
\hline $\begin{array}{l}\text { 23. I am actively involved in group activities in the } \\
\text { mathematics classroom. }\end{array}$ & $\begin{array}{c}0.52 \\
(0.79)\end{array}$ & $\begin{array}{c}1.16 \\
(0.76)\end{array}$ & -0.88 & -0.41 & 55 & -5.45 & $0.000 * *$ \\
\hline 24. I like to participate in classroom activities. & $\begin{array}{l}-0.32 \\
(0.96)\end{array}$ & $\begin{array}{c}0.32 \\
(1.11)\end{array}$ & -0.91 & -0.38 & 55 & -4.82 & $0.000^{* *}$ \\
\hline 27. I treat everyone with kindness and respect. & $\begin{array}{c}1.86 \\
(5.67)\end{array}$ & $\begin{array}{c}1.34 \\
(0.61)\end{array}$ & -1.00 & 2.04 & 55 & 0.68 & 0.497 \\
\hline 28. I accept that other people may disagree with me. & $\begin{array}{c}1.34 \\
(0.67)\end{array}$ & $\begin{array}{c}1.54 \\
(0.60)\end{array}$ & -0.35 & -0.04 & 55 & -2.51 & 0.015 * \\
\hline 31. I sacrifice myself for the benefit of others. & $\begin{array}{l}-0.05 \\
(0.80)\end{array}$ & $\begin{array}{c}0.20 \\
(0.92)\end{array}$ & -0.47 & -0.03 & 55 & -2.30 & $0.025 *$ \\
\hline 33. I would express my opinions, whether others agree or not. & $\begin{array}{c}0.34 \\
(0.96)\end{array}$ & $\begin{array}{c}0.61 \\
(0.95)\end{array}$ & -0.49 & -0.05 & 55 & -2.44 & 0.018 * \\
\hline 34. If setting a goal, I stay focused and conduct it. & $\begin{array}{c}0.64 \\
(0.84)\end{array}$ & $\begin{array}{c}1.07 \\
(0.76)\end{array}$ & -0.64 & -0.22 & 55 & -4.10 & $0.000^{* *}$ \\
\hline $\begin{array}{l}\text { 36. Listening to my peers' opinions during classroom } \\
\text { discussion is an important part of classroom participation. }\end{array}$ & $\begin{array}{c}1.05 \\
(0.67)\end{array}$ & $\begin{array}{c}1.25 \\
(0.67)\end{array}$ & -0.37 & -0.02 & 55 & -2.28 & $0.026^{*}$ \\
\hline
\end{tabular}

$$
\text { Note. }{ }^{* *} p<0.01,{ }^{*} p<0.05 \text {. }
$$

Table 10. Benefits of collaborative learning relative to character education.

\begin{tabular}{|c|c|c|c|c|c|c|c|}
\hline \multirow{2}{*}{ Statement } & \multirow{2}{*}{$\begin{array}{c}\text { Pre } \\
\text { M(SD) }\end{array}$} & \multirow{2}{*}{$\begin{array}{c}\text { Post } \\
\text { M(SD) }\end{array}$} & \multicolumn{2}{|c|}{$95 \%$ CI } & \multirow{2}{*}{$d f$} & \multirow{2}{*}{$t$} & \multirow{2}{*}{$p$} \\
\hline & & & LL & UL & & & \\
\hline $\begin{array}{l}\text { 21. If I can't solve a problem, I reach out for help in the } \\
\text { classroom. }\end{array}$ & $\begin{array}{l}1.07 \\
(0.74)\end{array}$ & $\begin{array}{c}1.34 \\
(0.77)\end{array}$ & -0.47 & -0.07 & 55 & -2.67 & $0.010^{*}$ \\
\hline $\begin{array}{l}\text { 25. I share my ideas with others when solving mathematics } \\
\text { problems. }\end{array}$ & $\begin{array}{c}0.64 \\
(0.96)\end{array}$ & $\begin{array}{l}1.16 \\
(0.83)\end{array}$ & -0.75 & -0.29 & 55 & -4.55 & $0.000 * *$ \\
\hline $\begin{array}{l}\text { 37. Socializing with other students is an important part of } \\
\text { working together. }\end{array}$ & $\begin{array}{c}1.38 \\
(0.84)\end{array}$ & $\begin{array}{c}1.66 \\
(0.61)\end{array}$ & -0.50 & -0.07 & 55 & -2.66 & 0.010 * \\
\hline $\begin{array}{l}\text { 38. I think that collaboration between the teacher and } \\
\text { students is an important learning process. }\end{array}$ & $\begin{array}{c}1.54 \\
(0.71)\end{array}$ & $\begin{array}{l}1.59 \\
(0.63)\end{array}$ & -0.25 & 0.14 & 55 & -0.55 & 0.582 \\
\hline $\begin{array}{l}\text { 39. Learning from others and their views supports my own } \\
\text { learning. }\end{array}$ & $\begin{array}{c}1.48 \\
(0.54)\end{array}$ & $\begin{array}{l}1.64 \\
(0.52)\end{array}$ & -0.34 & 0.02 & 55 & -1.84 & 0.071 \\
\hline $\begin{array}{l}\text { 40. Students can learn a great deal from talking in the } \\
\text { classroom and sharing ideas and experiences. }\end{array}$ & $\begin{array}{l}1.46 \\
(0.63)\end{array}$ & $\begin{array}{c}1.64 \\
(0.48)\end{array}$ & -0.37 & 0.01 & 55 & -1.87 & 0.067 \\
\hline
\end{tabular}

Note. ${ }^{* *} p<0.01,{ }^{*} p<0.05$.

Character and multirater feedback. In the case of character and multiple assessments, the participants cultivated character components such as responsibility (item 29), justice (item 30), and honesty (item 32) as shown below in Table 11.

The above cognitive changes in participant perceptions about character seemed to be related to the interactive process and the participants' reflections on the process of multirater feedback, as illustrated in the following excerpt:

[R]eflective learning experiences [through collaboration] are providing feedback to others and receiving feedback from others ... and interactive social skills with others can improve students' work ethic and responsibility. [Peer feedback] also helps students learn to evaluate their own and other people's learning objectively and be sensitive to [different ways of thinking]. (Excerpt 9-group presentation) 
Table 11. Benefits of multirater feedback relative to character education.

\begin{tabular}{|c|c|c|c|c|c|c|c|}
\hline \multirow{2}{*}{ Statement } & \multirow{2}{*}{$\begin{array}{c}\text { Pre } \\
\text { M(SD) }\end{array}$} & \multirow{2}{*}{$\begin{array}{c}\text { Post } \\
\text { M(SD) }\end{array}$} & \multicolumn{2}{|c|}{$95 \% \mathrm{CI}$} & \multirow{2}{*}{$d f$} & \multirow{2}{*}{$t$} & \multirow{2}{*}{$p$} \\
\hline & & & LL & UL & & & \\
\hline 26. I am responsible and keep my word. & $\begin{array}{c}1.13 \\
(0.69)\end{array}$ & $\begin{array}{l}1.16 \\
(0.68)\end{array}$ & -0.19 & 0.12 & 55 & -0.47 & 0.642 \\
\hline 29. I am reliable and don't pass my responsibility on to others. & $\begin{array}{c}1.00 \\
(0.71)\end{array}$ & $\begin{array}{c}1.32 \\
(0.72)\end{array}$ & -0.50 & -0.14 & 55 & -3.63 & $0.001^{* *}$ \\
\hline 30. I treat other students fairly and avoid prejudice. & $\begin{array}{c}0.59 \\
(0.89)\end{array}$ & $\begin{array}{c}0.88 \\
(0.81)\end{array}$ & -0.48 & -0.10 & 55 & -3.03 & $0.004^{* *}$ \\
\hline 32. I am honest. & $\begin{array}{c}0.79 \\
(0.73)\end{array}$ & $\begin{array}{c}1.11 \\
(0.73)\end{array}$ & -0.52 & -0.12 & 55 & -3.25 & $0.002^{* *}$ \\
\hline 35. I am a reflective person and act honestly. & $\begin{array}{c}0.63 \\
(0.80)\end{array}$ & $\begin{array}{c}0.82 \\
(0.79)\end{array}$ & -0.45 & 0.06 & 55 & -1.53 & 0.132 \\
\hline
\end{tabular}

Note. ${ }^{* *} p<0.01, * p<0.05$

\section{Discussion and Implications}

Our analysis of multiple sources of data indicates that our unit on creative character education was effective in developing preservice teachers' perceptions of creativity and character education. It also confirmed that the participants' changing perspectives towards the 6 practices actually reflected 8 of the 10 attributes of creativity and all of the 8 attributes of character education [7]. Further, the participants demonstrated a growing awareness of the potential opportunity and challenges of creative character education in mathematics. Specifically, the participants shaped a positive view towards the learning of mathematical content through storytelling, manipulatives, and representation activities in that the tool-mediated learning showed the potential to foster creativity in the mathematics classroom. The field of mathematics teacher education has begun to notice different needs of preservice teachers in each country facing various realities of social and cultural conditions [58]. For example, some U.S. mathematics teacher educators have a keen interest in training future teachers to provide equitable learning environments. Meanwhile, other mathematics teacher educators in Europe have produced a great deal of research on preparing future teachers for teaching mathematics with technology [59]. This study, grounded in the context of teaching mathematics in Korean classrooms, has identified the value of addressing both the content and process of mathematics and found that preservice teachers did develop an awareness and a positive conception towards character education in the learning of mathematics. As the participants engaged in communication with peers to explain and justify their thinking in collaborative tasks, they recognized the importance of mathematical confidence as an important mindset (see [60]) for the mathematics learner.

This study attended to the need for (future) mathematics educators in teacher education to recognize and develop an awareness of the importance of creative character education. Our findings can contribute to the efforts present in teacher education (see the discussion of the theory-practice divide in teacher education in [61]) to consider creative character education as part of the coursework and also to apply the acquired knowledge and skills into practice.

Our findings, including our model for introducing creativity and character education in mathematics as curriculum in teacher education, can provide insights for teacher educators in higher education as they design innovative curriculum for preservice mathematics teachers, especially those situated in the educational context of integrating creativity and character education with student learning.

With this in mind, some participants' critical views towards storytelling and the use of manipulatives and representations as the way to promote creativity are important to reflect on. As for storytelling, some participants regarded the pedagogical strategy as a content strand to teach. It then makes sense why they worried about assessing student performance on storytelling. Some stated storytelling is not mathematics. These concerns are valid to a degree, but what was likely not communicated clearly to the preservice teachers in the study is the importance of using a strategy to 
invoke student curiosity and help them relate to mathematics. Storytelling may be an effective tool to achieve this, rather than a piece of knowledge or skill to master. We note that Islim, Ozudogru, and Sevim-Cirak [62] reported that preservice teachers responded positively to using digital stories in their future teaching when they had the experience of creating one with digital technological tools.

Questioning the value of inductive reasoning, some participants implied that mathematics is abstract and thus facilitated by deductive reasoning. These views point to the challenges and opportunities in mathematics teacher education in higher education: preservice teachers (see related research on college students in [63]) need support to transition from a traditional, closed view of mathematics pedagogy to the reformed mindset [4] in which teachers are responsible for providing students with an intellectually safe space and with meaningful opportunities to learn mathematics.

\section{Limitations of the Study and Future Research}

There were several limitations to the study. Our data only included perceptions and discourse of preservice teachers; it did not include an actual classroom consisting of a teacher and students as a unit of analysis. Furthermore, our participants were already highly committed to mathematics education, and our findings may not be applicable to the way future educators who are not as interested or confident in mathematics conceptualize creativity and cooperative learning. We recommend future studies on the implementation of our pedagogy in the mathematics classroom and further investigation into (1) the effect of students' mathematical creativity and character building on their teaching practice in classroom contexts and (2) the way future educators in elementary schools or nonschool settings conceptualize mathematical creativity and character building. The classroom teachers' engagement in implementing creative character education, not only in secondary classrooms but also in a wide range of teaching contexts, can further contribute to the development of effective pedagogy of creative character education. Additionally, although our unit was successful in shaping how preservice teachers came to understand creative character education in the mathematics classroom, our survey instrument did not capture a meaningful change in views relating to the use of manipulatives to foster student fluency or the use of technology to foster mathematical precision in student thinking. Therefore, we recommend that mathematics teacher educators add additional tasks that enable preservice teachers to use manipulatives and technology to increase students' mathematical fluency and precision.

Presently, we need a line of work to develop advanced curriculum for teacher education that connects theory and practice, as well as professional development for teachers to implement creative character education in mathematics. Although our study frames creative character education through storytelling, the use of manipulatives and multiple representations, classroom norms, collaborative learning, and multirater feedback, we do not mean to argue that storytelling and the use of manipulatives and representations are the only teacher practices that promote student creativity, nor do we advocate that only certain teacher practices foster student character. We are hopeful that future research produces a variety of integrated teacher practices that afford students the opportunity to learn content, as well as experience a meaningful learning process, while adding to the literature that theorizes the values of creative character education in the mathematics classroom.

Author Contributions: Conceptualization, D.-J.K.; Data curation, S.-C.B. and S.-H.C.; Formal analysis, S.-C.B. and S.-H.C.; Funding acquisition, D.-J.K.; Investigation, S.-C.B.; Methodology, D.-J.K.; Project administration, D.-J.K.; Resources, D.-J.K., S.-C.B. and S.-H.C.; Software, S.-C.B. and S.-H.C.; Supervision, D.-J.K.; Validation, S.-C.B. and S.-H.C.; Visualization, D.-J.K., S.-C.B. and S.-H.C.; Writing-original draft, D.-J.K., S.-C.B., S.-H.C. and W.L.; Writing-review \& editing, H.-J.K. and W.L.

Funding: This research received no external funding.

Acknowledgments: Part of this work has been extended from an abstract titled "Impact of a creative character education program on pre-service teachers' perspectives and beliefs in learning mathematics" at the Joint Meeting of the International Group for the Psychology of Mathematics Education and the North American Chapter in Vancouver, Canada, 15 July-20 July 2014.

Conflicts of Interest: The authors declare no conflict of interest. 


\section{References}

1. Choi, S.; Kim, S. Psychology for Human Relationship; Pakyoungsa: Seoul, Korea, 2013.

2. Kwon, O.N.; Park, J.H.; Park, J.S. Cultivating divergent thinking in mathematics through an open-ended approach. Asia Pac. Educ. Rev. 2006, 7, 51-61. [CrossRef]

3. National Governors Association Center for Best Practices \& Council of Chief State School Officers. Common Core State Standards for Mathematics; Washington, DC, USA, 2010. Available online: http: / / www.corestandards.org/assets /CCSSI_Math\%20Standards.pdf (accessed on 11 February 2017).

4. National Council of Teachers of Mathematics (NCTM). Principles and Standards for School Mathematics; NCTM: Reston, VA, USA, 2000.

5. National Advisory Committee on Creative and Cultural Education. All Our Futures: Creativity, Culture and Education, National Advisory Committee on Creative and Cultural Education. 1999. Available online: https: / www.creativitycultureeducation.org/publication/all-our-futures-creativity-culture-andeducation (accessed on 22 May 2017).

6. Korean Ministry of Education. Creativity and Character Education. 2014. Available online: Retrievedfromhttp:/ / www.moe.go.kr (accessed on 17 March 2017).

7. Whang, W.; Kim, D.; Kim, W.; Lee, D.; Choi, S. Development and validation of a testing tool for mathematical creativity and character. Math. Educ. 2017, 56, 41-62. [CrossRef]

8. Choi, M. The effects of teacher education program for creativity education. J. Learn.-Cent. Curric. Instr. 2005, 10, 263-286.

9. Choi, M. The task and meaning of teacher creativity. J. Learn.-Cent. Curric. Instr. 2007, 7, 431-447.

10. Shin, J.; Kim, J.; Suh, B. Analysis of lectures for strengthening creativity and personality of pre-Mathematics teachers. J. Korean Sch. Math. Soc. 2017, 20, 255-275.

11. Lobato, J.; Rhodehamel, B.; Hohensee, C. “Noticing” as an alternative transfer of learning process. J. Learn. Sci. 2012, 21, 433-482. [CrossRef]

12. Wallas, G. The Art of Thought; Jonathan Cape: London, UK, 1926.

13. Sriraman, B. Are giftedness \& creativity synonyms in mathematics? An analysis of constructs within the professional and school realms. J. Second. Gift. Educ. 2005, 17, 20-36.

14. Liljedahl, P.; Sriraman, B. Musings on mathematical creativity. Learn. Math. 2006, 26, 17-19.

15. Zazkis, R.; Liljedahl, P. Teaching Mathematics as Storytelling; Sense Publishers: Rotterdam, The Netherlands, 2009.

16. Kattou, M.; Konotoyianni, K.; Pitta-Pentazi, D.; Christou, C. Connecting mathematical creativity to mathematical ability. ZDM. 2013, 45, 167-181. [CrossRef]

17. Ahn, B. An effect of storytelling in elementary mathematics textbooks. J. Elem. Math. Educ. Korea. 2014, 18, 19-35.

18. Son, J.; Jeong, E. Application and development of a storytelling, teaching-learning method using the science writing heuristic. J. Res. Curric. Instr. 2013, 17, 709-727.

19. Kim, Y.; Kim, J.; Park, S.; Park, K.; Lee, J. Developing the mathematics model textbook based on storytelling with real-life context. Commun. Math. Educ. 2013, 27, 179-203. [CrossRef]

20. Egan, K. The cognitive tools of children's imagination. In Proceedings of the 11th Annual European Conference on Quality in Early Childhood Education, Alkmaar, The Netherlands, 29 August-1 September 2001; pp. 2-24.

21. Kwon, O.N.; Park, J.H.; Park, J.S. Model lessons of mathematical practice focus on creativity and character education curriculum. Math. Educ. 2011, 50, 403-428. [CrossRef]

22. Lee, K.; Shim, S. A type analysis of students' responses for assessing creativity in activity using manipulative. Math. Educ. 2007, 46, 227-237.

23. Lee, J.; Choi, J. The effects of 4 D-frame teaching upon mathematically gifted elementary students mathematical creativity and spatial sense. Educ. Prim. Sch. Math. 2013, 16, 1-20. [CrossRef]

24. Bolden, D.S.; Harries, T.V.; Newton, D.P. Pre-service primary teachers' conceptions of creativity in mathematics. Educ. Stud. Math. 2010, 73, 143-157. [CrossRef]

25. Dienes, Z. Building Up Mathematics; Hutchinson Educational Ltd.: London, UK, 1960.

26. Lee, H.; Lee, K. The generalization of the area of internal triangles for the GSP use of mathematically gifted students. J. Korean Sch. Math. Soc. 2012, 15, 565-584. 
27. Shin, D.; Lew, H. Mathematics Education and Computers; Kyungmoonsa: Seoul, Korea, 1998.

28. Neel, K.S. Addressing diversity in the mathematics classroom with cultural artifacts. Math. Teach. Middle Sch. 2005, 11, 54-61.

29. Roberts, N.; Stylianides, A.J. Telling and illustrating stories of parity: A classroom-based design experiment on young children's use of narrative in mathematics. ZDM Int. J. Math. Educ. 2013, 45, 453-467. [CrossRef]

30. Hartshorn, R.; Boren, S. Experiential Learning of Mathematics: Using Manipulatives. ERIC Digest. (ED 321967); 1990. Available online: https://files.eric.ed.gov/fulltext/ED321967.pdf (accessed on 3 January 2018).

31. Bruner, J.S. Toward a Theory of Instruction; Belknap Press of Harvard: Cambridge, MA, USA, 1966.

32. Goldstone, R.L.; Son, J.Y. The transfer of scientific principles using concrete and idealized simulations. J. Learn. Sci. 2005, 14, 69-110. [CrossRef]

33. Fyfe, E.R.; McNeil, N.M.; Borjas, S. Benefits of concreteness fading for children's mathematics understanding. Learn. Instr. 2015, 35, 104-120. [CrossRef]

34. Kilpatrick, J.; Swafford, J.; Findell, B. (Eds.) Adding It Up: Helping Children Learn Mathematics; National Academies Press: Washington, DC, USA, 2001.

35. Goldin, G.; Shteingold, N. System of mathematical representations and development of mathematical concepts. In The Roles of Representation in School Mathematics: 2001 Yearbook; Curcio, F.R., Ed.; National Council of Teachers of Mathematics: Reston, VA, USA, 2001; pp. 1-23.

36. Duval, R. A cognitive analysis of problems of comprehension in a learning of mathematics. Educ. Stud. Math. 2006, 61, 103-131. [CrossRef]

37. Nucci, L.P.; Narvaez, D. Handbook of Moral and Character Education; Routledge: New York, NY, USA, 2008.

38. Gardner, H. Five Minds for the Future; Harvard Business Review Press: Cambridge, MA, USA, 2006.

39. Sternberg, R.J. WICS: A Model of Leadership in Organizations. Acad. Manag. Learn. Educ. 2003, 2, 386-401. [CrossRef]

40. Korean Ministry of Education (MOE). Revised National Curriculum in Mathematics; MOE: Seoul, Korea, 2015.

41. Keyser, C.J. Humanism and Science; Columbia University Press: New York, NY, USA, 1996.

42. Woo, J.H. Educational Basics of School Mathematics; Seoul National University press: Seoul, Korea, 1998.

43. Johnson, D.W.; Johnson, R.T. New developments in social interdependence theory. Genet. Soc. Gen. Psychol. Monogr. 2005, 131, 285-358. [CrossRef] [PubMed]

44. Lopez, L.; Allal, L. Sociomathematical norms and the regulation of problem solving in classroom microcultures. Int. J. Educ. Res. 2007, 46, 252-265. [CrossRef]

45. Seo, K.; Ahn, J. The inquiry of change of mathematical beliefs and attitude in elementary cooperative learning class. Sch. Math. 2003, 5, 541-553.

46. Choi, W.; Jung, H. The effect of self-assessment on self-direct learning ability of gifted students. J. Sci. Educ. Gift. 2010, 2, 45-71.

47. National Council of Teachers of Mathematics (NCTM). Assessment Standards for School Mathematics; NCTM: Reston, VA, USA, 1995.

48. Cobb, P.; Yackel, E. Constructivist, emergent, and sociocultural perspectives in the context of developmental research. Educ. Psychol. 1996, 31, 175-190.

49. Simon, M.A.; Blume, G.W. Justification in the mathematics classroom: A study of prospective elementary teachers. J. Math. Behav. 1996, 15, 3-31. [CrossRef]

50. Dishion, T.; Piehler, T. Deviant by design: Peer contagion in development, interventions, and schools. In Handbook on Peer Interactions, Relationships, and Groups; Rubin, K., Bukowski, W., Laursen, B., Eds.; Guilford: New York, NY, USA, 2009; pp. 589-602.

51. Johnson, D.W.; Johnson, R.T. An educational psychology success story: Social interdependence theory and cooperative learning. J. Educ. Res. 2009, 38, 365-379. [CrossRef]

52. Cohen, B.P.; Cohen, E.G. From groupwork among children to R \& D teams: Interdepence, interaction and productivity. In Advances in Group Processes; Lawler, E.J., Markovsky, B., Ridgeway, C., Walker, H., Eds.; JAI Publishing: Greenwich, CT, USA, 1991; pp. 205-226.

53. London, M.; Smither, J.W. Can multisource feedback change self-awareness and behavior? Theoretical applications and directions for research. Pers. Psychol. 1995, 48, 803-840. [CrossRef] 
54. Leikin, R. Exploring mathematical creativity using multiple solution tasks. In Creativity in Mathematics and the Education of Gifted Students; Leikin, R., Berman, A., Koichu, B., Eds.; Sense Publishers: Rotterdam, The Netherlands, 2009; pp. 129-145.

55. Johnson, R.B.; Onwuegbuzie, A.J. Mixed methods research: A research paradigm whose time has come. Educ. Res. 2004, 33, 14-26. [CrossRef]

56. Lim, C.P. Global Citizenship education, school curriculum and games: Learning mathematics, English and science as a global citizen. Comput. Educ. 2008, 51, 1073-1093. [CrossRef]

57. Lee, J.; Kang, K.; Kim, Y.; Kang, S. Statistical Methods for Social Sciences; Pakyoungsa: Seoul, Korea, 2007.

58. Artigue, M.; Winsløw, C. International comparative studies on mathematics education: A viewpoint from the Anthropological Theory of Didactics. Res. Didact. Math. 2010, 31, 47-82.

59. Hoyles, C.; Lagrance, J.-B. (Eds.) Mathematics Education and Technology-Rethinking the Terrain; Springer: New York, NY, USA; Berlin, Germnay, 2010.

60. Boaler, J. Mathematical Mindsets: Unleashing Students' Potential through Creative Math, Inspiring Messages and Innovative Teaching; Jossey-Bass: San Francisco, CA, USA, 2016.

61. Flores, M.A. Practice, theory and research in initial teacher education: International perspectives. Eur. J. Teach. Educ. 2017, 40, 287-290. [CrossRef]

62. Islim, O.F.; Ozudogru, G.; Sevim-Cirak, N. The use of digital storytelling in elementary math teachers' education. Educ. Media Int. 2018, 55, 107-122. [CrossRef]

63. Muis, K.R. Personal epistemology and mathematics: A critical review and synthesis of research. Rev. Educ. Res. 2004, 74, 317-377. [CrossRef]

(c) 2019 by the authors. Licensee MDPI, Basel, Switzerland. This article is an open access article distributed under the terms and conditions of the Creative Commons Attribution (CC BY) license (http://creativecommons.org/licenses/by/4.0/). 